\title{
Evolution and Revolution of Hepatitis C Management: From Non-A, Non-B Hepatitis Toward Global Elimination
}

\author{
Viktorija Basyte-Bacevice ${ }^{a}$ Juozas Kupcinskas ${ }^{a, b}$ \\ a Department of Gastroenterology, Lithuanian University of Health Sciences, Kaunas, Lithuania; \\ ${ }^{\mathrm{b}}$ Institute for Digestive Research, Lithuanian University of Health Sciences, Kaunas, Lithuania
}

\section{Keywords}

Hepatitis C virus · Hepatology · Liver

\begin{abstract}
Discovery of hepatitis C in 1989 allowed basic research to identify critical components of hepatitis C virus (HCV) structure and life cycle. Interferon (IFN)-a was introduced as first treatment for chronic hepatitis $C$ and later was enhanced by pegylation, addition of ribavirin, and resulted in improved sustained virologic response. Better understanding of $\mathrm{HCV}$ structure, enzymes, and lifecycle led to the discovery of direct-acting antivirals and IFN-free era. Successful HCV therapy created a rare possibility of global disease eradication, which is now a major goal internationally. However, hepatitis $C$ remains a major public health challenge, and more resources are needed to reach global elimination.
\end{abstract}

(c) 2020 S. Karger AG, Basel

\section{Introduction}

This review article summarizes a fascinating history of hepatitis $\mathrm{C}$ virus (HCV). Here in this paper, we cover historical aspects of $\mathrm{HCV}$ discovery, early treatment options, and breakthroughs brought by direct-acting antiviral
(DAA) drugs. The review is also aimed to discuss remaining challenges and future steps needed for global HCV elimination in the next decades.

\section{Non-A, Non-B Hepatitis, and Discovery of Hepatitis C}

In the 1960s, viral hepatitis was first classified as classical infectious hepatitis, characterized by short incubation period, short period of abnormal serum transaminase activity, and high degree of contagiousness or as serum hepatitis that had longer incubation and abnormal serum transaminase activity periods, was moderately contagious, and could result in chronic hepatitis [1]. In 1965, Blumberg et al. [2] discovered Australia antigen, later named the hepatitis B surface antigen ( $\mathrm{HBsAg}$ ), that was linked to viral hepatitis and at that time considered to be the main cause of serum hepatitis $[3,4]$. In order to prevent posttransfusion hepatitis, sensitive tests for HBsAg were developed [5]. Donor screening for HBsAg reduced posttransfusion hepatitis cases by $50 \%$; however, there still were some hepatitis cases, despite the fact that patients received only blood that was HBsAg negative [6]. In 1975, Feinstone et al. [7] detected hepatitis A virus in stool of infected patients and when serological test to detect both hepatitis A virus and HBV were developed, it was found
(C) 2020 S. Karger AG, Basel
Juozas Kupcinskas

Department of Gastroenterology and Institute for Digestive Research

Lithuanian University of Health Sciences

Eiveniu Street 2, LT-50009 Kaunas (Lithuania)

E-Mail juozas.kupcinskas@ 1smuni.lt 
that parenterally transmitted hepatitis is caused by another virus, named "non-A, non-B" hepatitis (NANBH) [8]. Chimpanzee studies showed that multiple NANBH agents are present, and one of them is small enveloped agent that causes membranous tubules within the cytoplasm of hepatocytes [9-11]. Simultaneously, progression to liver cirrhosis [12], as well as to hepatocellular carcinoma [13], was confirmed in NANBH patients. Hoofnagle et al. [14] started a pilot study where NANBH was treated with interferon (IFN)- $\alpha 2 b$. Those were the same regimens that showed to be effective in treating patients infected with hepatitis B. Results revealed that on IFN therapy serum aminotransferase levels decreased rapidly [14]. Despite these findings, over a decade of intensive laboratory research was needed to finally discover the disease-causing agent. In 1989, the NANBH virus genome was cloned and sequenced by Houghton et al. [16] and called HCV [15]. This discovery allowed sensitive tests to detect HCV and eliminate the virus from the blood transfusion supply.

\section{Cracking the Structure of Hepatitis C}

After successful identification of HCV, following genetic analyses revealed complete sequence of the HCV genome which consists of a positive-stranded RNA molecule of approximately 9,600 nucleotides $[17,18]$. The genome consists of an open reading frame encoding a polyprotein precursor of 3,010 amino acids [19]. Translation and replication of the HCV open reading frame are directed via a 340 nucleotide long $5^{\prime}$ untranslated region. The HCV polyprotein is cleaved by host and viral proteases into 10 different products, with the structural proteins (core, E1 and E2) and the nonstructural (NS2-5) replicative proteins [19]. HCV is an enveloped virus [20] that replicates in hepatocytes [21]. While envelope glycoproteins E1 and E2 help virus to enter the hepatocyte [21], liver-specific microRNA-122 contributes to stability, translation, and replication of the HCV RNA [22, 23]. $\mathrm{HCV}$ is a member of Flaviviridae family and belongs to Hepacivirus [20]. It also has a similar genome organization as Pestivirus (bovine viral diarrhea, classical swine fever), Flavivirus (yellow fever, zikavirus, dengue virus), and Pegivirus (human virus GBV-C) [20, 24]. In 1993, phylogenetic analyses revealed high genetic heterogeneity of the virus and classified HCV into 6 genotypes (GTs) [25-27]. Subtypes 1a, 1b, 2a, 2b, 3a, 4a, 5a, and 6a are currently the ones which are studied in detail [28]. In 2014, Smith et al. [29] reported GT7, more recently GT8 was confirmed in 4 patients from India [30]. A global survey found that HCV GT1 and 3 are the most prevalent GTs and account for 46 and $30 \%$ of all HCV cases, respectively; GTs2, 4, 5, and 6 accounted for the majority of remaining cases: $9,8,1$, and $6 \%$, respectively [31]. Today, exact determination of GT and subtype provide us not only with information about geographical prevalence in different countries but also is important for targeted anti$\mathrm{HCV}$ treatment.

\section{Historical Treatment Options for Hepatitis C}

After first attempts to treat $\mathrm{HCV}$ patients with IFNa2b [14], 2 randomized controlled trials were started. One study administered 2 million units of IFN- $\alpha 2 b$ versus placebo 3 times weekly [32], another study used either 3 or 1 million units versus placebo 3 times weekly [33]. In both studies, the course of treatment lasted for 6 months. The results showed that IFN- $\alpha 2 b$ was efficient in reducing disease activity; however, after the cessation of treatment, many patients relapsed $[32,33]$. To assess the effect of IFN- $\alpha 2 b$ therapy, HCV RNA levels were detected in another study, which confirmed that HCV RNA was successfully decreased or eradicated in some patients after IFN- $\alpha 2 b$ therapy [34]. After these studies, IFN- $\alpha 2 b$ was officially approved for chronic hepatitis C treatment; however, frequent side effects, high relapse rate, and average sustained viral response (SVR) [35] suggested that another agent was needed. The first attempts to treat chronic hepatitis $\mathrm{C}$ with ribavirin monotherapy were initiated in early 1990s. The results were immediate: ALT levels decreased rapidly, but after discontinuation of the treatment, almost in all patients, ALT levels rose back to pretreatment levels $[36,37]$. These findings led to the initiation of clinical trials, where INF- $\alpha$ was combined with ribavirin in patients with chronic hepatitis $\mathrm{C}[38,39]$. In both studies, patients were randomized to receive INF- $\alpha$ alone or along with ribavirin, and results showed that combined therapy was significantly associated with higher SVR or even complete HCV RNR clearance. After large-scale multicenter randomized trials confirmed these findings $[35,40]$, the combination of INF- $\alpha$ and ribavirin was approved as a standard treatment of chronic hepatitis C in 1999. INF- $\alpha 2 b$ and ribavirin were administered 3 times per week, and for many patients, this regimen was difficult and related to the rapid clearance of the drug [41]. To maintain a steady level of an active drug and reduce the frequency of administration, pegylated INF$a 2 b$ (PegINF- $a 2 b$ ) was developed. Following studies showed that PegINF- $\alpha 2 b$ was superior to the unpegylated 


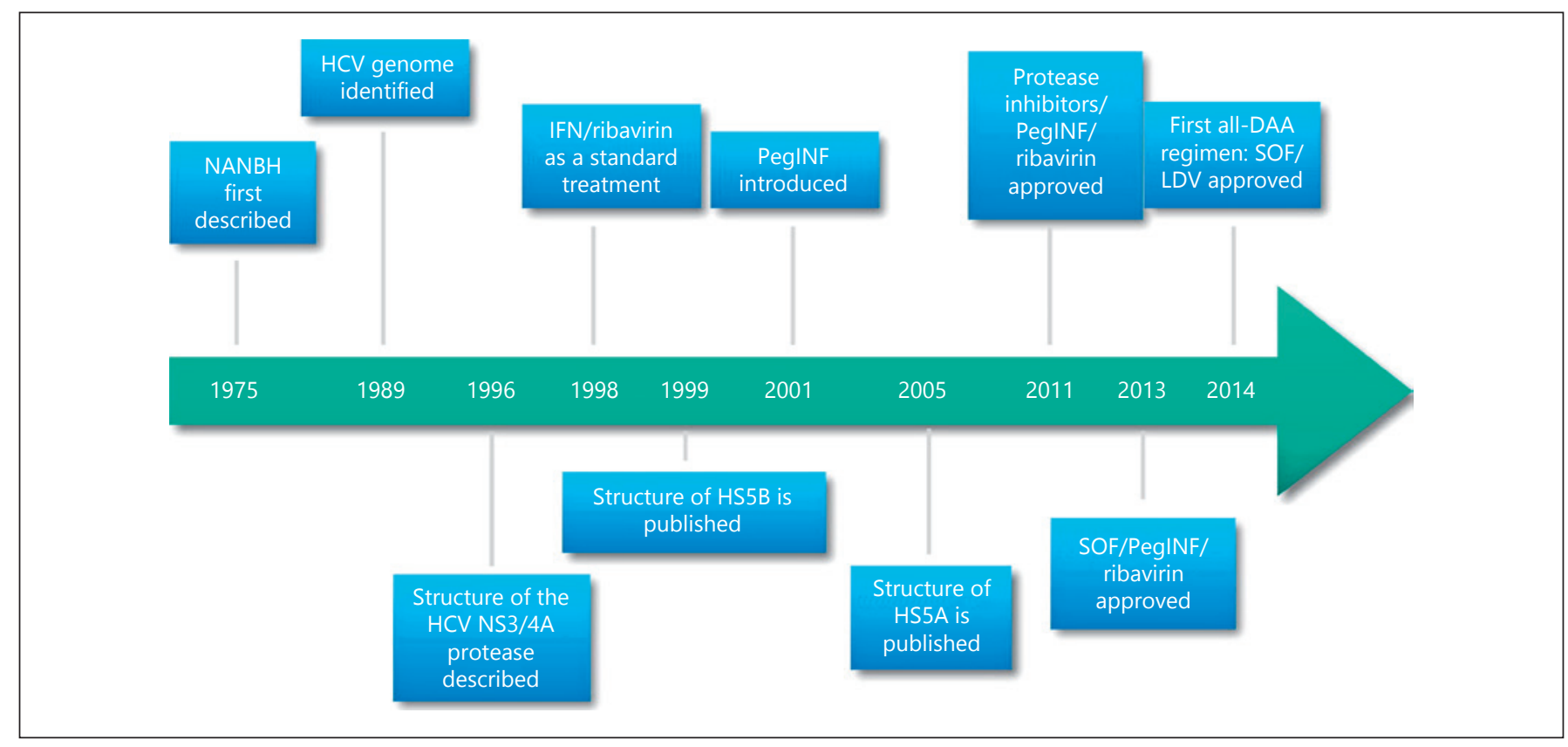

Fig. 1. Timeline of milestones in hepatitis $C$ discovery and treatment. $H C V$, hepatitis $C$ virus; NANBH, non-A non-B hepatitis; IFN, interferon, PegIFN, pegylated interferon; SOF, sofosbuvir, LDV, ledipasvir; DAA, directacting antiviral; NS, nonstructural.

IFN [41], and new combination of PegINF- $\alpha 2 b$ and ribavirin became the standard choice of hepatitis $C$ treatment for the next 10 years. During these years, treatment response and duration were determined by measuring HCV RNA levels at baseline, weeks 4, 12, and 24, at the end of treatment, and 24 weeks after treatment [42]. Genome-wide association studies also contributed by identifying single nucleotide polymorphism located in interleukin-28B ( $r s 12979860)$, which is strongly associated with positive INF- $\alpha$ treatment response and spontaneous HCV clearance [43]. However, better understanding of $\mathrm{HCV}$ structure, enzymes, and lifecycle led to the introduction of new drug targets and the discovery of DAAs.

\section{DAA Drugs}

In 2011, first DAAs (telaprevir and boceprevir), used in combination with PegINF- $\alpha$ and ribavirin, were officially approved for HCV GT1 treatment [42]. Both drugs are NS3-4A protease inhibitors and their effect results in inhibition of HCV replication. Despite the fact that clinical trials results were promising, adverse events and serious complications showed that there is a need for improvement [44-46]. After a few years of intensive research, safer and more effective DAAs were developed
(Figure 1). In 2013, simeprevir was approved in combination with PegINF- $\alpha$ and ribavirin for HCV GT1 and showed less side effects with same SVR rates [47]. The same year sofosbuvir, an NS5B polymerase inhibitor, was developed and showed to be effective against all HCV GTs $[48,49]$. It was approved as a part of therapy for HCV GT1 and GT4 with PegINF- $\alpha$ and for GT2 and GT3 with ribavirin. After 3 clinical trials found that DAAs can be used alone for HCV GT1 treatment with SVR rates of 94-99\% and with significantly less side effects, in 2014, FDA approved first all-DAAs regimen with sofosbuvir/ ledipasvir and sofosbuvir/simeprevir [50-53]. To date there are many available EMEA- and FDA-approved DAAs for HCV treatment, which are classified according to their chemical structure: protease NS3 inhibitors (glecaprevir, grazoprevir, paritaprevir, simeprevir, voxilaprevir), NS5A serine protease inhibitors (daclatasvir, elbasvir, ledipasvir, ombitasvir, pribrentasvir, velpatasvir), NS5B RNA-dependent RNA nucleoside polymerase (sofosbuvir), and non-nucleoside polymerase (dasabuvir) inhibitors [54]. These drugs differ in their action mechanism against the different HCV GTs and their combinations enable higher barrier to resistance [55]. Because of their virological efficacy, ease of use, safety, and tolerability DAA-based regimens are being used in $\mathrm{HCV}$-infected patients without cirrhosis and with compensated cirrho- 


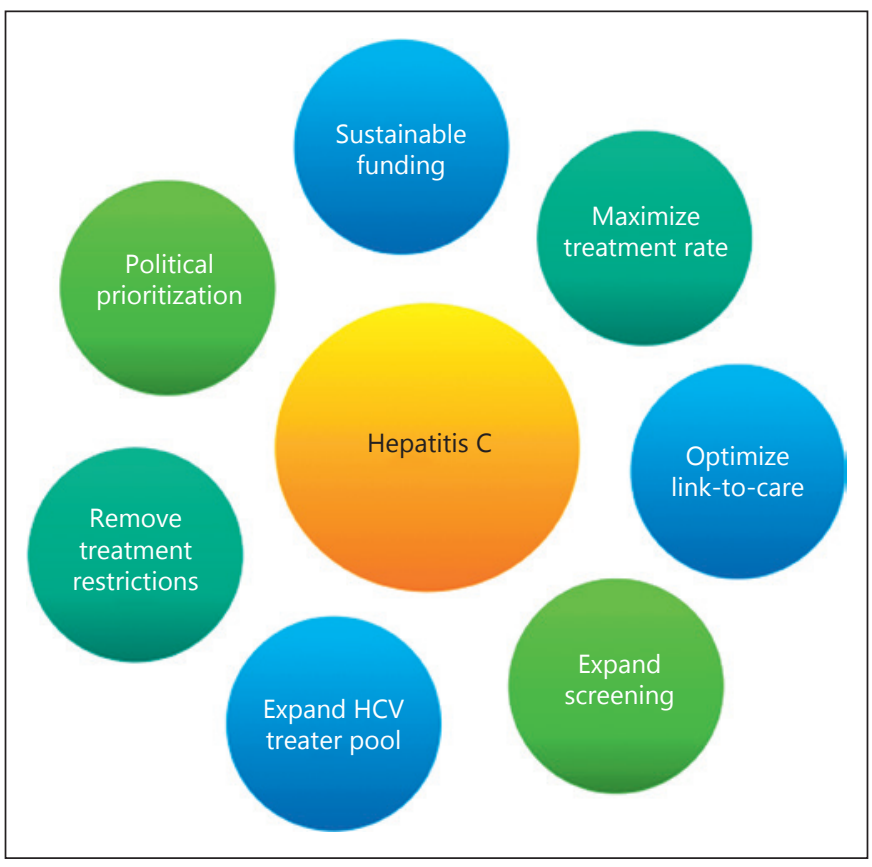

Fig. 2. Hepatitis $\mathrm{C}$ elimination challenges. $\mathrm{HCV}$, hepatitis $\mathrm{C}$ virus.

sis, "treatment-naïve" patients, and in patients who were previously treated with IFN and ribavirin [56]. The success in HCV therapy created a rare possibility of local disease elimination or even global disease eradication. To achieve this, more effective, well tolerated, and highly available therapy is still needed in the future.

\section{Heading Toward Global Elimination of Hepatitis C in 2030}

Hepatitis B and C infections remain one of the dominant causes of liver-related deaths [57]. Globally, in 2015, 257 million people were living with chronic HBV infection, 71 million people with chronic HCV infection, and 1.75 million new HCV infections occurred worldwide [58]. Major public health activities are needed to combat viral hepatitis and reduce burden of these chronic diseases. In 2016, the World Health Assembly adopted the Global Health Sector Strategy to eliminate viral hepatitis by 2030 [58-60]. The WHO goal for HCV infection is to decrease number of incidence by approximately $90 \%$ and reduce number of HCV-related deaths by approximately $65 \%$ in 2030 [60]. Key public health interventions for both HBV and $\mathrm{HCV}$ were determined: $\mathrm{HBV}$ vaccination, prevention of mother to child transmission of $\mathrm{HBV}$, injection and blood safety, harm reduction, test and treatment of $\mathrm{HBV}$ and HCV [60]. To successfully cut down the incidence of hepatitis $\mathrm{C}$, it is needed to improve education on injection safety and vein care, appropriately screen blood transfusions, reduce the use of unnecessary injections, and provide sterile syringes and medication-assisted treatment to people who inject drugs $[60,61]$. Elimination of HCV-related deaths depends on efficacious test and treatment strategy. While HCV-specific antibodies can be detected up to $99 \%$ sensitivity and specificity, there are many difficulties in diagnosing $\mathrm{HCV}$ infection, mainly because $\mathrm{HCV}$ infections are asymptomatic [60]. Also, reaching high-risk groups, such as people who inject drugs and prison inmates, is always difficult and requires specific public health interventions. The remaining elimination challenges are lack of political prioritization, insufficient funding for HCV treatment and screening, treatment restrictions applied by physicians (e.g., for patients with psychological disorders, substance abuse), insufficient number of treaters, no systematic screening, and diagnosis programs and suboptimal linkage to care [60-62] (Figure 2). Lack of financial resources also remains the major obstacle to eliminate hepatitis by 2030 . Worldwide, the commitment to develop national plans is improving. As of March 2017, 43 WHO Member States have reported that they have developed national plans, and 36 have reported that plans are in progress; however, only a few countries included hepatitis treatment and prevention strategies for all patients in their national hepatitis programs [57, 62]. According to Polaris data, Australia, Iceland, Switzerland, Italy, Mongolia, Spain, Egypt, France, Georgia, Japan, Netherlands, and United Kingdom are on their way to achieve the WHO hepatitis elimination targets $[63,64]$. In low-income countries, current hepatitis B and C treatment rates are very low and strong financial and political will, support from civil societies, and support from pharmaceutical and medical companies is needed $[65,66]$.

\section{Conclusion}

The remarkable history of the discovery of HCV and an exciting era in HCV treatment could lead to an exceptional possibility of global elimination of the virus. However, drug price reduction and international collaboration are compulsory to obtain this goal.

\section{Disclosure Statement}

J.K. has received speaker fees from AbbVie and Merck. 


\section{Funding Sources}

No additional funding was received.

\section{Author Contributions}

V.B.-B. and J.K.: contributed in data analysis and writing original manuscript. J.K. contributed in reviewing and editing manuscript. V.B.-B. contributed in visualization of manuscript. All authors reviewed and approved of the final manuscript.

\section{References}

1 Krugman S, Giles JP, Hammond J. Infectious hepatitis. Evidence for two distinctive clinical, epidemiological, and immunological types of infection. JAMA. 1967 May;200(5):365-73.

2 Blumberg BS, Alter HJ, Visnich S. A "new" antigen in Leukemia Sera. JAMA. 1965 Feb; 191(7):541-6.

3 Krugman S, Giles JP. Viral hepatitis. New light on an old disease. JAMA. 1970 May; 212(6):1019-29.

4 Prince AM. An antigen detected in the blood during the incubation period of serum hepatitis. Proc Natl Acad Sci USA. 1968 Jul;60(3): 814-21.

5 Gocke DJ. A prospective study of posttransfusion hepatitis. The role of Australia Antigen. JAMA. 1972 Feb;219(9):1165-70.

6 Alter HJ, Holland PV, Purcell RH, Lander JJ, Feinstone SM, Morrow AG, et al. Posttransfusion hepatitis after exclusion of commercial and hepatitis-B antigen-positive donors. Ann Intern Med. 1972 Nov;77(5):691-9.

7 Feinstone SM, Kapikian AZ, Purceli RH. Hepatitis A: detection by immune electron microscopy of a viruslike antigen associated with acute illness. Science. 1973 Dec; 182(4116): 1026-8.

8 Feinstone SM, Kapikian AZ, Purcell RH, Alter HJ, Holland PV. Transfusion-associated hepatitis not due to viral hepatitis type A or B. N Engl J Med. 1975 Apr;292(15):767-70.

9 Alter HJ, Purcell RH, Holland PV, Popper H. Transmissible agent in non-A, non-B hepatitis. Lancet. 1978 Mar;1(8062):459-63.

10 Hollinger FB, Gitnick GL, Aach RD, Szmuness W, Mosley JW, Stevens CE, et al. Non-A, non- $B$ hepatitis transmission in chimpanzees: a project of the transfusion-transmitted viruses study group. Intervirology. 1978;10(1):608.

11 Shimizu YK, Feinstone SM, Purcell RH, Alter HJ, London WT. Non-A, non-B hepatitis: ultrastructural evidence for two agents in experimentally infected chimpanzees. Science. 1979 Jul;205(4402):197-200.

12 Alter HJ, Purcell RH, Shih JW, Melpolder JC, Houghton M, Choo QL, et al. Detection of antibody to hepatitis $C$ virus in prospectively followed transfusion recipients with acute and chronic non-A, non-B hepatitis. N Engl J Med. 1989 Nov;321(22): 1494-500.

13 Colombo M, Kuo G, Choo QL, Donato MF, Del Ninno E, Tommasini MA, et al. Prevalence of antibodies to hepatitis $\mathrm{C}$ virus in Ital- ian patients with hepatocellular carcinoma. Lancet. 1989 Oct;2(8670):1006-8.

14 Hoofnagle JH, Mullen KD, Jones DB, Rustgi V, Di Bisceglie A, Peters M, et al. Treatment of chronic non-A,non-B hepatitis with recombinant human alpha interferon. A preliminary report. N Engl J Med. 1986 Dec; 315(25):1575-8.

15 Choo QL, Kuo G, Weiner AJ, Overby LR, Bradley DW, Houghton M. Isolation of a cDNA clone derived from a blood-borne non-A, non- $B$ viral hepatitis genome. Science. 1989 Apr;244(4902):359-62.

16 Houghton M. Discovery of the hepatitis C virus. Liver Int. 2009 Jan;29(Suppl 1):82-8.

17 Kato N, Hijikata M, Ootsuyama Y, Nakagawa M, Ohkoshi S, Sugimura T, et al. Molecular cloning of the human hepatitis $\mathrm{C}$ virus genome from Japanese patients with non-A, non-B hepatitis. Proc Natl Acad Sci USA. 1990 Dec;87(24):9524-8.

18 Choo QL, Richman KH, Han JH, Berger K, Lee $\mathrm{C}$, Dong $\mathrm{C}$, et al. Genetic organization and diversity of the hepatitis $\mathrm{C}$ virus. Proc Natl Acad Sci USA. 1991 Mar;88(6):2451-5.

19 Ashfaq UA, Javed T, Rehman S, Nawaz Z, Riazuddin S. An overview of HCV molecular biology, replication and immune responses. Virol J. 2011 Apr;8(1):161.

20 Simmonds P, Becher P, Bukh J, Gould EA, Meyers G, Monath T, et al.; Ictv Report Consortium. ICTV Virus Taxonomy Profile: flaviviridae. J Gen Virol. 2017 Jan;98(1):2-3.

21 Wieland S, Makowska Z, Campana B, Calabrese D, Dill MT, Chung J, et al. Simultaneous detection of hepatitis $\mathrm{C}$ virus and interferon stimulated gene expression in infected human liver. Hepatology. 2014 Jun;59(6): 2121-30.

22 Gottwein JM, Bukh J. Chapter 2: Cutting the Gordian Knot-Development and Biological Relevance of Hepatitis C Virus Cell Culture Systems. Advances in Virus Research [cited 2019 Aug 10]. Academic Press; 2008. pp. 51133 [Internet]. Available from: http://www. sciencedirect.com/science/article/pii/ S006535270800002X

23 Jopling CL, Yi M, Lancaster AM, Lemon SM, Sarnow P. Modulation of hepatitis $C$ virus RNA abundance by a liver-specific MicroRNA. Science. 2005 Sep;309(5740):1577-81.

24 Stapleton JT, Foung S, Muerhoff AS, Bukh J, Simmonds P. The GB viruses: a review and proposed classification of GBV-A, GBV-C (HGV), and GBV-D in genus Pegivirus with- in the family Flaviviridae. J Gen Virol. 2011 Feb;92(Pt 2):233-46.

25 Bukh J, Purcell RH, Miller RH. At least 12 genotypes of hepatitis $\mathrm{C}$ virus predicted by sequence analysis of the putative E1 gene of isolates collected worldwide. Proc Natl Acad Sci USA. 1993 Sep;90(17):8234-8.

26 Bukh J, Miller RH, Purcell RH. Genetic heterogeneity of hepatitis $C$ virus: quasispecies and genotypes. Semin Liver Dis. 1995 Feb; 15(1):41-63.

27 Simmonds P, Holmes EC, Cha TA, Chan SW, McOmish F, Irvine B, et al. Classification of hepatitis $C$ virus into six major genotypes and a series of subtypes by phylogenetic analysis of the NS-5 region. J Gen Virol. 1993 Nov; 74(Pt 11):2391-9.

28 Simmonds P. The Origin of Hepatitis C Virus. In: Bartenschlager R, editor. Hepatitis C Virus: From Molecular Virology to Antiviral Therapy [Internet]. Berlin, Heidelberg: Springer Berlin Heidelberg; 2013. p. 1-15 [cited 2019 Aug 10]. Available from: https://doi. org/https://doi.org/10.1007/978-3-64227340-7_1.

29 Smith DB, Bukh J, Kuiken C, Muerhoff AS, Rice CM, Stapleton JT, et al. Expanded classification of hepatitis $\mathrm{C}$ virus into 7 genotypes and 67 subtypes: updated criteria and genotype assignment web resource. Hepatology. 2014 Jan;59(1):318-27.

30 Borgia SM, Hedskog C, Parhy B, Hyland RH, Stamm LM, Brainard DM, et al. Identification of a Novel Hepatitis C Virus Genotype From Punjab, India: Expanding Classification of Hepatitis C Virus Into 8 Genotypes. J Infect Dis. 2018 Oct;218(11):1722-9.

31 Messina JP, Humphreys I, Flaxman A, Brown A, Cooke GS, Pybus OG, et al. Global distribution and prevalence of hepatitis $C$ virus genotypes. Hepatology. 2015 Jan;61(1):7787.

32 Di Bisceglie AM, Martin P, Kassianides C, Lisker-Melman M, Murray L, Waggoner J, et al. Recombinant interferon alfa therapy for chronic hepatitis C. A randomized, doubleblind, placebo-controlled trial. N Engl J Med. 1989 Nov;321(22):1506-10.

33 Davis GL, Balart LA, Schiff ER, Lindsay K, Bodenheimer HC Jr, Perrillo RP, et al.; Hepatitis Interventional Therapy Group. Treatment of chronic hepatitis $\mathrm{C}$ with recombinant interferon alfa. A multicenter randomized, controlled trial. N Engl J Med. 1989 Nov; 321(22):1501-6. 
34 Shindo M, Di Bisceglie AM, Cheung L, Shih JW, Cristiano K, Feinstone SM, et al. Decrease in serum hepatitis $\mathrm{C}$ viral RNA during alphainterferon therapy for chronic hepatitis C. Ann Intern Med. 1991 Nov;115(9):700-4.

35 Poynard T, Marcellin P, Lee SS, Niederau C, Minuk GS, Ideo G, et al.; International Hepatitis Interventional Therapy Group (IHIT) Randomised trial of interferon $\mathrm{a} 2 \mathrm{~b}$ plus ribavirin for 48 weeks or for 24 weeks versus interferon $\mathrm{a} 2 \mathrm{~b}$ plus placebo for 48 weeks for treatment of chronic infection with hepatitis C virus. Lancet. 1998 Oct;352(9138):1426-32.

36 Reichard O, Andersson J, Schvarcz R, Weiland O. Ribavirin treatment for chronic hepatitis C. Lancet. 1991 May;337(8749):1058-61.

37 Di Bisceglie AM, Shindo M, Fong TL, Fried MW, Swain MG, Bergasa NV, et al. A pilot study of ribavirin therapy for chronic hepatitis C. Hepatology. 1992 Sep;16(3):649-54.

38 Brillanti S, Garson J, Foli M, Whitby K, Deaville R, Masci C, et al. A pilot study of combination therapy with ribavirin plus interferon alfa for interferon alfa-resistant chronic hepatitis C. Gastroenterology. 1994 Sep;107(3):812-7.

39 Schvarcz R, Ando Y, Sönnerborg A, Weiland O. Combination treatment with interferon alfa- $2 \mathrm{~b}$ and ribavirin for chronic hepatitis $\mathrm{C}$ in patients who have failed to achieve sustained response to interferon alone: swedish experience. J Hepatol. 1995;23(Suppl 2):17-21.

40 McHutchison JG, Gordon SC, Schiff ER, Shiffman ML, Lee WM, Rustgi VK, et al.; Hepatitis Interventional Therapy Group. Interferon alfa-2b alone or in combination with ribavirin as initial treatment for chronic hepatitis C. N Engl J Med. 1998 Nov;339(21): 1485-92.

41 Lindsay KL, Trepo C, Heintges T, Shiffman ML, Gordon SC, Hoefs JC, et al.; Hepatitis Interventional Therapy Group. A randomized, double-blind trial comparing pegylated interferon alfa-2b to interferon alfa-2b as initial treatment for chronic hepatitis C. Hepatology. 2001 Aug;34(2):395-403.

42 European Association for Study of Liver. EASL Clinical Practice Guidelines: management of hepatitis $\mathrm{C}$ virus infection. J Hepatol. 2014 Feb;60(2):392-420.

43 Ge D, Fellay J, Thompson AJ, Simon JS, Shianna KV, Urban TJ, et al. Genetic variation in IL28B predicts hepatitis $\mathrm{C}$ treatment-induced viral clearance. Nature. 2009 Sep;461(7262): 399-401.

44 Jacobson IM, McHutchison JG, Dusheiko G, Di Bisceglie AM, Reddy KR, Bzowej NH, et al.; ADVANCE Study Team. Telaprevir for previously untreated chronic hepatitis $\mathrm{C}$ virus infection. N Engl J Med. 2011 Jun;364(25): 2405-16.

45 Sherman KE, Flamm SL, Afdhal NH, Nelson DR, Sulkowski MS, Everson GT, et al.; ILLUMINATE Study Team. Response-guided telaprevir combination treatment for hepatitis $\mathrm{C}$ virus infection. N Engl J Med. 2011 Sep; 365(11):1014-24.

46 Poordad F, McCone J Jr, Bacon BR, Bruno S, Manns MP, Sulkowski MS, et al.; SPRINT-2 Investigators. Boceprevir for untreated chronic HCV genotype 1 infection. N Engl J Med. 2011 Mar;364(13):1195-206.

47 Manns M, Marcellin P, Poordad F, de Araujo ES, Buti M, Horsmans Y, et al. Simeprevir with pegylated interferon alfa $2 \mathrm{a}$ or $2 \mathrm{~b}$ plus ribavirin in treatment-naive patients with chronic hepatitis $\mathrm{C}$ virus genotype 1 infection (QUEST-2): a randomised, double-blind, placebo-controlled phase 3 trial. Lancet. 2014 Aug;384(9941):414-26.

48 Membreno FE, Lawitz EJ. The HCV NS5B nucleoside and non-nucleoside inhibitors. Clin Liver Dis. 2011 Aug;15(3):611-26.

49 Lawitz E, Mangia A, Wyles D, RodriguezTorres M, Hassanein T, Gordon SC, et al. Sofosbuvir for previously untreated chronic hepatitis C infection. N Engl J Med. 2013 May; 368(20):1878-87.

50 Afdhal N, Reddy KR, Nelson DR, Lawitz E, Gordon SC, Schiff E, et al.; ION-2 Investigators. Ledipasvir and sofosbuvir for previously treated HCV genotype 1 infection. N Engl J Med. 2014 Apr;370(16):1483-93.

51 Afdhal N, Zeuzem S, Kwo P, Chojkier M, Gitlin N, Puoti M, et al.; ION-1 Investigators. Ledipasvir and sofosbuvir for untreated HCV genotype 1 infection. N Engl J Med. 2014 May;370(20):1889-98.

52 Kowdley KV, Gordon SC, Reddy KR, Rossaro L, Bernstein DE, Lawitz E, et al.; ION-3 Investigators. Ledipasvir and sofosbuvir for 8 or 12 weeks for chronic HCV without cirrhosis. N Engl J Med. 2014 May;370(20):1879-88.

53 Lawitz E, Sulkowski MS, Ghalib R, Rodriguez-Torres M, Younossi ZM, Corregidor A, et al. Simeprevir plus sofosbuvir, with or without ribavirin, to treat chronic infection with hepatitis $C$ virus genotype 1 in non-responders to pegylated interferon and ribavirin and treatment-naive patients: the COSMOS randomised study. Lancet. 2014 Nov;384(9956): 1756-65.

54 Zając M, Muszalska I, Sobczak A, Dadej A, Tomczak S, Jelińska A. Hepatitis C - New drugs and treatment prospects. Eur J Med Chem. 2019 Mar; 165:225-49.

55 Pawlotsky JM, Feld JJ, Zeuzem S, Hoofnagle $\mathrm{JH}$. From non-A, non-B hepatitis to hepatitis C virus cure. J Hepatol. 2015 Apr;62(1 Suppl):S87-99.

56 Pawlotsky JM, Negro F, Aghemo A, Berenguer M, Dalgard O, Dusheiko G, et al.; European Association for the Study of the Liver. Electronic address: easloffice@easloffice.eu; European Association for the Study of the Liver. EASL Recommendations on Treatment of Hepatitis C 2018. J Hepatol. 2018 Aug; 69(2):461-511.

57 Gore C, Hicks J, Deelder W. Funding the elimination of viral hepatitis: donors needed. Lancet Gastroenterol Hepatol. 2017 Dec; 2(12):843-5.

58 WHO. | Global hepatitis report, 2017 [Internet]. [cited 2019 Aug 31]. Available from: https://www.who.int/hepatitis/publications/ global-hepatitis-report2017/en/.

59 Resolution adopted by the General Assembly on 25 September 2015. Transforming our world: the 2030 Agenda for Sustainable Development [Internet]. European Environment Agency. Available from: https://www. eea.europa.eu/policy-documents/resolutionadopted-by-the-general.

60 WHO. Global health sector strategy on viral hepatitis 2016-2021 [Internet]. Available from: http://www.who.int/hepatitis/strategy2016-2021/ghss-hep/en/.

61 Thomas DL. Global Elimination of Chronic Hepatitis. N Engl J Med. 2019 May;380(21): 2041-50.

62 World Health Organization (2016). Global report on access to hepatitis $\mathrm{C}$ treatment. Focus on overcoming barriers. World Health Organization. Available from: https://apps. who.int/iris/handle/10665/250625.

63 World Health Organization. Progress report on access to Hepatitis C treatment, focus on overcoming barriers in low and middle income countries. Available from: http://apps. who.int/iris/bitstream/10665/260445/1/ WHO-CDS-HIV-18.4-eng.pdf?ua=1.

64 Polaris Observatory. Center for Disease Analysis. Available from: http://cdafound.org/polaris/.

65 Waheed Y. Hepatitis C eradication: A long way to go. World J Gastroenterol. 2015 Nov; 21(43):12510-2.

66 Waheed Y, Siddiq M, Jamil Z, Najmi MH Hepatitis elimination by 2030: progress and challenges. World J Gastroenterol. 2018 Nov; 24(44):4959-61. 